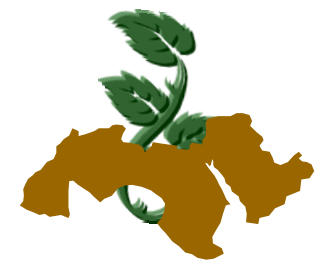

Arab Univ.

J. Agric. Sci., Ain Shams Univ., Cairo, 22(1), 55-65, 2014

\title{
INFLUENCE OF VERMICOMPOST AND PLANT DENSITY ON SUSTAINABLE PRODUCTION OF PEAS
}

\author{
Abul-Soud', M.; K.M. Refaie ${ }^{1}$ and R.E. Abdelraouf ${ }^{2}$ \\ 1. Central Laboratory for Agricultural Climate, Agricultural Research Center, Dokki 12411, \\ Giza, Egypt \\ 2. Water Relations \& Field Irrigation Dept., National Research Center, Dokki, Giza, Egypt
}

Keywords: Organic fertilizer, Base fertilizer, Vermicomposting, Vermicompost, Cattle manure, Pea production, Plant density, Yield and quality

\section{ABSTRACT}

The need to increase the organic soil matter for sustainable production to match food security under semi-arid Egyptian conditions (high temperature, low preception, shortage of organic fertilizer etc..) led to looking for new sources of oragnic materials such as modern composting technologies and increase the effeiency of recycling. The field experiment was carried out during the two winter successive seasons of 2011 and 2012 under open field conditions in protected cultivation site, Central Laboratory for Agriculture Climate (CLAC), Agriculture Research Centre, Giza, Egypt. Peas (Pisum sativum), cv. Lincolin was used in this study. The study aimed to investigate the use of vermicompost as alternative organic fertilizer by different rates (15, 20 and $25 \mathrm{~m}^{3} /$ feddan) compared to cattle manure $\left(20 \mathrm{~m}^{3} / \mathrm{feddan}\right.$ as a control) combained with two plant distances (30 and $50 \mathrm{~cm}$ ) which performed in split plot design. The obtained results indicate that increasing the rate of vermicompost from 15 to $25 \mathrm{~m}^{3} /$ feddan led to increase the values of physical and chemical properties of both pea plants and yield characteristics. The highest vegetative growth characteristics were recorded by application rate of $25 \mathrm{~m}^{3} / \mathrm{feddan}$ combined with $50 \mathrm{~cm}$ plant distance followed by $20 \mathrm{~m}^{3} /$ feddan combined with $30 \mathrm{~cm}$ compared to the other treatments. The application rate of vermicompost $25 \mathrm{~m}^{3} / \mathrm{feddan}$ combined with plant distance $30 \mathrm{~cm}$ gave the highest yield of peas per feddan. Concerning, the highest fruit quality parameters were estimated under application rate of vermicompost 20 $\mathrm{m}^{3} /$ feddan combined with $50 \mathrm{~cm}$. The recommended treatment under this study conditions was the use of vermicompost $25 \mathrm{~m}^{3} /$ feddan combined with $30 \mathrm{~cm}$ followed by $20 \mathrm{~m}^{3} / \mathrm{feddan}$ combined with 30 $\mathrm{cm}$ of plant distance. The vermicomposting of organic wastes and applied it to the soil as an organic fertilizer instead of burial or inceneration led to store $\mathrm{CO}_{2}$ in the soil and decrease its emission.

\section{INTRODUCTION}

Environmental degradation is a major threat confronting the world and the rampant use of chemical fertilizers contributes largely to the deterioration of environment, less agricultural productivity, loss of soil fertility and soil degradation (Inbar et al 1993). Semi-arid soils are deficient in all the necessary plant nutrients and at the same time large quantities of such nutrients found in domestic wastes and agricultural byproducts which are negligible and wasted. It is estimated that in cities and rural areas of Egypt nearly 80 million tones of organic wastes are generated annually creating disposal problems on environment, gas emessions and public health which are either burned or land filled. These wastes can be converted into valuable compost by applying vermi-composting technology. Different organic wastes can be used in vermicompost production by different species of earthworms which include horse waste (Edwards et al 1998; Garg and Kaushik, 2005); cattle dung (Edwards et al 1985, 1998; Bansal and Kapoor, 2000; Kaushik and Garg, 2003) cow slurry (Hand et al 1988); urban solid waste (Alves and Passoni, 1997); city leaf litter and food wastes (Logsdon, 1994; Singh and Sharma, 2002); paper waste and residues of plant decomposition. However, Kamergam et al (1999) mentioned that integrated effect of all the nutrients present in vermicompost increased growth of Pisum sativum plants in a very short period of time and gave rise to high crop 
yield as compared to pit compost and garden soil (control).

Plant density is a major factor in affecting the productivity of the yield, and is particularly important in large-seeded species such as field pea where the cost of sowing large quantities of seed become a significant issue compared to cereals (Adisarwanto and Knight 1997; Armstrong et al 2008; Marcellos and Constable 1986; Matthews et al 2001, McMurray, 2004, McRae et al 2008). Plant density can affect early ground cover (Jettner et al 1998b), competitive ability with weeds (Lemerle et al 2004; Lemerle et al 2006), soil surface evaporation, light interception (Jettner et al 1998b) and development of an optimum number of fruiting sites in a crop canopy to maximize grain yield (Jettner et al 1998a and b). In this regard, considerable attention has been paid by some workers on pea showed that out of the three rows spacing 20,30 and $40 \mathrm{~cm}$ adopted with a constant plant spacing of $7.5 \mathrm{~cm}$ proved that, the closest spacing of $20 \times 7.5 \mathrm{~cm}$ recorded the highest plant height. On cowpeas spacing significantly influenced the growth and yield where the maximum grain yield and net returns were obtained with $45 \mathrm{~cm}$ spacing. Seed rate generally influenced the plant height, number of pods/plant, number of grains/pod, and 100 grain weight and grain yield (Sharma, 2002; Kumari and Ushakumari, 2002). On the same crop, peas, testing four row spacing $40,60,80$ and $100 \mathrm{~cm}$ exhibited that pods yield linearly decreased with the increase in row spacing showing that the least row spacing of $40 \mathrm{~cm}$ resulted in the highest yield (Sajid et al 2012).

Sustainable agriculture needs sustained support of organic fertilizers and good practices of organic wastes. Vermicomposting secures friendly environment and the recycling of organic wastes creates the base for offering high nutrients value compost for sustainable agriculture. The main objectives of this study are the transferring and localize the know-how of vermicomposting besides establishing scientific base for the uses of vermicomposting in Egypt while sustained supply of organic fertilizer to soil and increase the productivity of peas take in high consider beside the investigating the effect of plant spacing on crop yield.

\section{MATERIALS AND METHODS}

This study was conducted out at the Protected Cultivation Site, Central Laboratory for Agriculture Climate (CLAC), Agriculture Research Centre, Giza, Egypt. The vermicomposting process was done during the summer seasons of 2011 and
2012 and the open field experiments on peas were established during the following winter seasons.

\subsection{The vermicomposting proccess}

The system of vermicomposting was established in 10 bins form on concrete base by using bricks banded together with cement $1.25 \times 4 \times 0.75$ $\mathrm{m}$ diamensions. Each system contained $10 \mathrm{~kg}$ of the epigiec earthworms Lumbriscus Rubellus (Red Worm), Eisenia Fetida (Tiger Worm), Perionyx Excavatus (Indian Blue) and Eudrilus Eugeniae (African Night Crawler) which were used in the vermicomposting bins. The average worm diameter ranged btween $0.5-5 \mathrm{~mm}$ and the worm length between 10 to $120 \mathrm{~mm}$. The epigiec earthworm consume as much as their weight of the different organic wastes.

Every day during the hot summer season, the growing beds turned and watering carefully to offer the aeration and prevent the anaropic condition. Shreded newspaper was used to cover the bins so as to minmize drying during hot summer weather and keep moisture content in the range of $60-70 \%$. Every 21 days, the growing beds were fasting for 7 days to give the earthworms the opportunity to reeat the cast and to avoid non composted wastes.

Mixing the different raw materials which were cattle manure + kitchen wastes + newspaper at the ratio $2: 2: 1$ by using turning machine and precomposting the materials for 7 to 10 days to avoid the thermphilic stage (the increase in temperature) of composting which cause the death of earthworms in vermicompost systems. The use of newspapers, cardboard and any fiber material used as a bulk material and water agent should not over than $20 \%$ of proccessing waste. The final mix were soaked in water for half to one hour to make sure that there was no any more dry parts, then put it in lines along the bed with the soaked water. The chemical composition of the different agricultural wastes is prsesnted in Table (1).

\subsection{The field experiment}

After vermicompost isolation, the field experiment was carried out under open field conditions to investigate the effect of the three rates of vermicompost 15,20 and $25 \mathrm{~m}^{3} /$ feddan beside the cattle manure at $20 \mathrm{~m}^{3} / \mathrm{feddan}$ as a control for comparison. Two plant distances in the row at 30 and $50 \mathrm{~cm}$ were applied. The different rates of vermicompost and cattle manure added to the soil 2 weeks before the cultivation of winter peas through the preparation of soil to avoid any damage or burning of the plants. 
Table 1. The chemical composition (\%) of the different agricultural wastes

\begin{tabular}{|lcccccc|}
\hline \multirow{2}{*}{ Raw material } & \multirow{2}{*}{ C/N ratio } & \multicolumn{5}{c|}{ Macro elements \% } \\
\cline { 3 - 7 } & & $\mathrm{N}$ & $\mathrm{P}$ & $\mathrm{k}$ & $\mathrm{Ca}$ & $\mathrm{Mg}$ \\
\hline Cattle manure $(C M)$ & 22.00 & 1.83 & 0.56 & 1.38 & 1.13 & 1.06 \\
Kitchen wastes $(K W)$ & 62.60 & 0.34 & 0.19 & 0.64 & 0.81 & 0.43 \\
Newspaper $(N)$ & 166.81 & 0.016 & 0.01 & 0.00 & 0.20 & 0.01 \\
$C M+K W+N$ & 67.26 & 0.90 & 0.31 & 0.73 & 0.81 & 0.59 \\
\hline
\end{tabular}

Table 2. Chemical and physical analyses of the soil at Dokki site

\begin{tabular}{|c|c|c|c|c|c|c|c|c|c|}
\hline \multirow{2}{*}{ Soil depth } & \multicolumn{9}{|c|}{ Chemical properties } \\
\hline & \multicolumn{2}{|c|}{$\begin{array}{c}\text { ECe } \\
\text { mmohs }\end{array}$} & $\mathrm{pH}$ & $\begin{array}{l}\mathbf{C a}^{++} \\
\mathrm{meg} / \mathrm{L}\end{array}$ & $\underset{\mathrm{meg} / \mathrm{L}}{\mathbf{M g}^{++}}$ & $\begin{array}{l}\mathrm{Na}^{+} \\
\mathrm{meg} / \mathrm{L}\end{array}$ & $\underset{\mathrm{meg} / \mathrm{L}}{\mathbf{K}^{+}}$ & $\underset{\mathrm{meg} / \mathrm{L}}{\mathrm{Hco}}$ & $\begin{array}{l}\text { CL- } \\
\mathrm{meg} / \mathrm{L}\end{array}$ \\
\hline \multirow{4}{*}{$\begin{array}{c}0-30 \\
\mathrm{Cm}\end{array}$} & 2. & & 7.6 & 5.05 & 1.8 & 9.0 & 4.15 & 2.9 & 10.8 \\
\hline & \multicolumn{9}{|c|}{ Physical properties } \\
\hline & $\underset{\%}{\text { Sand }}$ & Clay & $\underset{\%}{\text { Silt }}$ & Texture & $\begin{array}{c}\text { SP } \\
\%\end{array}$ & $\begin{array}{c}\mathbf{F C} \\
\%\end{array}$ & & & $\begin{array}{l}\text { BD } \\
\mathrm{g} / \mathrm{cm}^{3}\end{array}$ \\
\hline & 15.9 & 76.6 & 7.5 & Clay & 22.5 & 32.0 & & & 1.25 \\
\hline
\end{tabular}

The chemical (Chapman and Pratt 1961) and physical properties of the clay experimental soil were determined before cultivation and vermicompost applications (Table 2). The saturation point \% (SP), field capacity \% (FC), wilting point \% (WP) and bulk density $\mathrm{g} / \mathrm{cm}^{3}$ (BD) of the soil were determined according to Israelsen \& Hansen (1962). The organic soil matter of the experiment was determined before vermicompost application and after two months from harvesting the peas in both the first and second seasons. The remain canopy of peas was chopped and turned over with the soil for increasing the organic soil matter.

Peas (Pisum sativum, L), cv. Lincolin was used in this study. Sowing was done at the first of October for the two seasons. Pea seeds soaked overnight in water and treated by Rhizobium inoculation (microbin) to encourage both germination and microbial nodules. Two seeds were placed at 30 and $50 \mathrm{~cm}$ in the row where the distance between the rows was $60 \mathrm{~cm}$ (2 rows/bed) and between the beds was $70 \mathrm{~cm}$. Pea plants were irrigated by using drippers of $4 \mathrm{l} / \mathrm{hr}$ capacity. The chemical fertilizers were injected within irrigation water system. The fertigation was programmed to work 2 times / day and the duration of irrigation time depended upon the season. All the other agriculture practices of peas cultivation were in accordance with the standard recommendations for commercial growers by Agriculture Research center (ARC). Ministry of Agriculture, Egypt.
Plant height $(\mathrm{cm})$, number of branches / plant, dry weight ( $\mathrm{g} /$ plant), total leaves area $\left(\mathrm{cm}^{2}\right)$ estimated by using leaf area meter, leaf area index, total chlorophyll content $(\mathrm{mg} / \mathrm{g})$ determined by using spectrophotometer (Wettstein, 1957). Total yield of green pods (tone/feddan), No. of pods / plant, yield of dry seed ( $\mathrm{kg} / \mathrm{feddan})$, weight of 100 dry seeds (g), No. of dry seeds/plant, protein content (\%) and total carbohydrate (\%) of dry seeds were determined at the harvesting stages acording to Smith et al (1956).

For mineral analysis of leaves and dry seeds $(\mathrm{N}, \mathrm{P}$ and $\mathrm{K} \%$ ) determinations take place at the beginning of fruiting stage and at the end of harvesting, Three samples of the plant and seeds from each plot were dried at $70^{\circ} \mathrm{C}$ in an air forced oven for $48 \mathrm{~h}$. Dried leaves and seeds were digested in $\mathrm{H}_{2} \mathrm{SO}_{4}$ according to the method described by Allen (1974) and N, P and K contents were determined in the acid digested solution by colorimetric method (ammonium molybdate) using spectrophotometer and flame photometer Chapman and Pratt, (1961). Total nitrogen was determined by Kjeldahl method according to the procedure described by FAO (1980). Phosphorus content was determined by using spectrophotometer according to Watanabe and Olsen (1965). Potassium content was determined photo-metrically using the Flame photometer as described by Chapman and Pratt (1961). 
The calculations of sequestrate $\mathrm{CO}_{2}$ and save the nutrients in the soil were calculated as follows:

$$
\begin{aligned}
\text { Sequestrate } \mathrm{CO}_{2}(\mathrm{Kg} / \text { tone })= & \mathrm{C} \%(\text { raw material }) \times 10 \\
\text { Nutrient save }(\mathrm{Kg} / \text { tone }) & = \\
& \text { Nutrient } \%(\text { after } \\
& \text { composting }) \times 10
\end{aligned}
$$

The experimental design was split plot with 3 replicates where vermicompost rates and control were assigned as main plots and plant distances as subplots. Analysis of the data was done by computer, using SAS program for statistical analysis and the differences among means for all traits were tested for significance at $5 \%$ level (Waller and Duncan 1969).

\section{RESULTS AND DISCUSSION}

\subsection{The effect of vermicomposting proccess on raw materials}

The results in Table (3) showed that the vermicomposting proccess increased the total $\mathrm{N}, \mathrm{P}, \mathrm{K}$, $\mathrm{Ca}$ and $\mathrm{Mg} \%$ of the vermicompost as compared to that of the raw materials while $\mathrm{C} / \mathrm{N}$ ratio decreased as a result of $\mathrm{N}$ fixation, concentrated the nutrients and bulk reduction.

The vermicomposting proccess through using Lumbriscus Rubellus (Red Worm ), Eisenia Fetida (Tiger Worm), Perionyx Excavatus (Indian Blue) and Eudrilus Eugeniae (African Night Crawler) led to produce rich, dark, earth-smelling soil conditioner from neglectable sources of raw materials and offer organic fertilizer for sustainable agriculture. It should be realized that vermicomposting allows obtaining organic sources of nutrients for the crops in relatively less time, which are physically, nutritionally and biochemically improved in the obtained composts. Never the less, vermicomposting is defined as a low cost technology system for processing organic wastes (Hand et al 1988). More information proved that earthworms act as mechanical blenders besides fragmenting the organic matter which modify its physical and chemical status by gradually reducing the ratio of $\mathrm{C}: \mathrm{N}$ and increasing the surface area exposed to microorganisms inducing much more favorable media for microbial activity and further decomposition (Domínguez et al 2010). In addition, the nutrient save ( $\mathrm{Kg} /$ tone) via using vermicomposting proccess from nonsignificant organic sources such as kitchen wastes and newspapers gave good evidences on recycling the urban organic wastes and the application of the output. Needless to say that the most important point of utilizing vermicompost- ing was mitigating the $\mathrm{CO}_{2}$ emission through sequestration of the organic carbon into the soil. However, the determined calaculation measured the organic carbon of organic wastes used in this study that treated by vermicomposting and stored in the soil was estimated by $605.3 \mathrm{Kg}$ per each tone.

\subsection{The effect of organic application on organ- ic soil matter}

The data in Fig. (1) show the organic soil matter content (\%) of the soil's experiment which was meseaured before the first season application of vermicompost and after 1.5 months from harvesting peas in both seasons. The obtained results presented that the increase of vermicompost rate from 15 to $25 \mathrm{~m}^{3} /$ feddan consequantly increased the organic soil matter content (\%). On the other hand, the application of in-row plant space of 30 $\mathrm{cm}$ recorded the higher value of organic soil matter content $(\%)$ compared to $50 \mathrm{~cm}$. The increase in organic soil matter content (\%) induced gradual increases during the management of organic fertilizer and the recycling of peas canopy into the soil. The sustainable production was affected to great extend by the increase of organic soil matter content (\%) which in turn increased the soil fertility. However, the highest value of organic soil matter content (\%) resulted from addition of vermicompost rate at $25 \mathrm{~m}^{3} / \mathrm{feddan}$ that compined with $30 \mathrm{~cm}$ plant distance followed by $20 \mathrm{~m}^{3} /$ feddan compined with $30 \mathrm{~cm}$. It is reasonable to say that adding of vermicompost increased the surface area, provides strong absorbability, retained more nutrients for a longer period of time, had significantly greater soil bulk density and less compactness (Lunt and Jacobson, 1994).

The recycling of organic wastes for maintenance of soil health by hygienic methods is vital for increasing crop production and welfare of mankind. The incorporation of organic matter remain in the form of compost, farmyard manure, cereal residue and green manure which influence favorably the physical, chemical and biological properties of the soil. It was reported that composting is the most important and rewarding method for increasing agricultural output by raising the level of soil fertility through improving the long-term structural stability, moisture retention of the soil and the supply of plant nutrients (Dalzell et al 1987). The current study focus on the organic soil matter content as a strong indicator while much of the research work on vermicompost has focused on studying plant 
Table 3. The chemical composition (\%) of the raw material before and after vermicomposting and nutrient save $(\mathrm{Kg} /$ tone)

\begin{tabular}{|lcccccc|}
\hline Vermicomposting & $\mathrm{C} / \mathrm{N}$ ratio & $\mathrm{N}(\%)$ & $\mathrm{P}(\%)$ & $\mathrm{K}(\%)$ & $\mathrm{Ca}(\%)$ & $\mathrm{Mg}(\%)$ \\
\hline Before & 67.26 & 0.90 & 0.31 & 0.73 & 0.81 & 0.59 \\
After & 12.8 & 1.46 & 0.59 & 1.06 & 1.08 & 0.89 \\
Nutrient Save (Kg/tone) & 605.3 & 14.6 & 5.9 & 10.6 & 10.8 & 8.9 \\
\hline
\end{tabular}

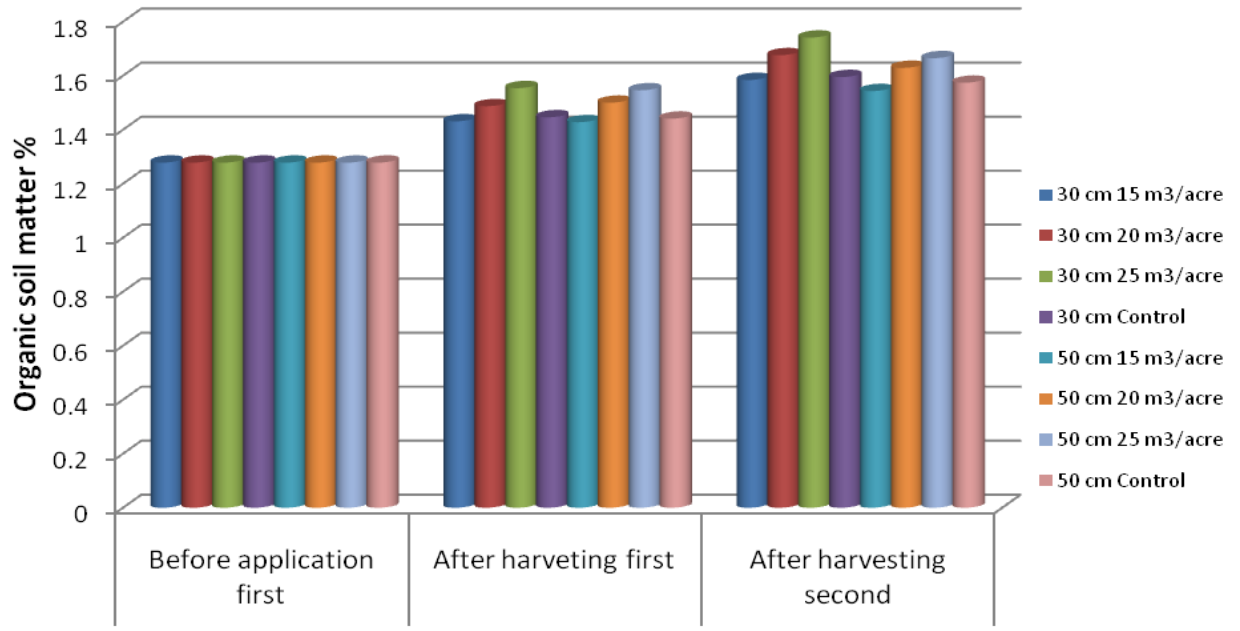

Fig. 1. The effect of vermicompost applications and plant spacing on average of organic soil matter content of the soil's experiment

available nutrients and changes in soil structure via soil porosity, aeration, and moisture holding capacity. (Hashemimajd et al 2004 and Tejada et al 2010). From another point of view, aging of vermicompost has been studied focusing on microbiological or physical/chemical changes for up to 60 days duration (Aira et al 2007).

\subsection{The effect of vermicompost and plant dis- tances on properties of peas plant}

The results in Table (4) illustrate the effects of vermicompost rates, planting distances and their interaction on some physical and chemical propertis of pea plant. Regarding the effect of vermicompost rate, the data of plant height, No. of branches / plant, dry weight, total leaves area, leaf area index, total chlorophyll content, N, P and $\mathrm{K}$ leaves content are presented in Table (4). The results indicate that the increase of the vermicompost rate from 15 to $25 \mathrm{~m}^{3} /$ feddan led to significant increase in the above mentioned data except $\mathrm{P}$ content.
This tendency of the increase in the previous characteristics may be due to the increase in the soil organic matter and the mineral content. However, there was no significant difference between 20 and $25 \mathrm{~m}^{3} /$ feddan of vermicompost. The treatment of cattle manure $20 \mathrm{~m}^{3} / \mathrm{feddan}$ (control) recorded significantly the second level after the treatments of 20 and $25 \mathrm{~m}^{3} / \mathrm{feddan}$ of vermicompost.

The in-row plant distance of $50 \mathrm{~cm}$ gave the highest figures of physical and chemical properties of pea plant exept leaf $\mathrm{P}$ content (\%) as compared to $30 \mathrm{~cm}$. Increasing in-row plant distance led to enhence the vegetative growth and the contents of $\mathrm{N}$ and $\mathrm{K}$ in leaves. Significant differences between treatments were true during both seasons.

The interaction between the vermicompost at $25 \mathrm{~m}^{3} /$ feddan combined with in-row distance $50 \mathrm{~cm}$ followed by $20 \mathrm{~m}^{3} /$ feddan combined with in-row space $50 \mathrm{~cm}$ recorded the highest results of plant height, No. of branches / plant, dry weight, total leaves area, leaf area index and the contents of total chlorophyll, $\mathrm{N}$ and $\mathrm{K}$ in leaves. These results 
Table 4. Effect of vermicomposting \%, planting Spaces and their interaction on some physical and chemical properties of pea plant

\begin{tabular}{|c|c|c|c|c|c|c|c|c|c|c|c|c|c|c|c|c|c|c|}
\hline $\begin{array}{l}\text { Treatment } \\
\text { Vermicompost } \\
\text { rate }(A)\end{array}$ & \multicolumn{2}{|c|}{$\begin{array}{l}\text { Plant } \\
\text { height } \\
\text { cm }\end{array}$} & \multicolumn{2}{|c|}{$\begin{array}{l}\text { No. of } \\
\text { bran./ } \\
\text { plant }\end{array}$} & \multicolumn{2}{|c|}{$\begin{array}{l}\text { Dry weight } \\
\text { g/plant }\end{array}$} & \multicolumn{2}{|c|}{$\begin{array}{l}\text { Leaf area } \\
\mathrm{cm}^{2} / \text { plant }\end{array}$} & \multicolumn{2}{|c|}{$\begin{array}{l}\text { Leaf area } \\
\text { index } \\
\mathrm{cm}^{2}\end{array}$} & \multicolumn{2}{|c|}{$\begin{array}{l}\text { Chlorophyll } \\
\text { (mg/g fresh } \\
\text { weight) }\end{array}$} & \multicolumn{2}{|c|}{$\mathrm{N} \%$ leaves } & \multicolumn{2}{|c|}{ P \% leaves } & \multicolumn{2}{|c|}{$\begin{array}{c}\mathrm{K} \% \\
\text { leaves }\end{array}$} \\
\hline \multicolumn{19}{|c|}{ First season } \\
\hline $15 \mathrm{~m}^{3} / \mathrm{feddan}$ & 75.8 & C & 2.7 & C & 17.3 & B & 1208 & C & 3.9 & $\mathrm{C}$ & 0.51 & B & 4.1 & B & 0.5 & A & 3.7 & B \\
\hline $20 \mathrm{~m}^{3} / \mathrm{feddan}$ & 91.2 & A & 4.4 & $A$ & 24.3 & A & 1812 & A & 6.4 & $A$ & 0.61 & A & 4.4 & A & 0.4 & B & 5.0 & A \\
\hline $25 \mathrm{~m}^{3} / \mathrm{feddan}$ & 92.5 & A & 4.7 & A & 24.7 & A & 1842 & A & 6.2 & $A$ & 0.62 & A & 4.3 & A & 0.4 & $B$ & 5.0 & A \\
\hline Control & 80.5 & B & 4.1 & B & 19.8 & B & 1572 & B & 5.7 & B & 0.55 & B & 4.0 & B & 0.5 & A & 4.1 & B \\
\hline \multicolumn{19}{|l|}{ Planting Space (B) } \\
\hline $30 \mathrm{~cm}$ & 79.8 & $B$ & 3.7 & $B$ & 19.4 & B & 1417 & B & 5.3 & $\mathrm{~B}$ & 0.50 & B & 4.1 & B & 0.5 & A & 4.2 & B \\
\hline $50 \mathrm{~cm}$ & 90.3 & A & 4.3 & A & 23.7 & A & 1800 & $A$ & 5.8 & $A$ & 0.59 & A & 4.4 & A & 0.4 & B & 4.7 & A \\
\hline \multicolumn{19}{|l|}{ Interaction $A^{\star} B$} \\
\hline $15 \mathrm{~m}^{3 *} 30 \mathrm{~cm}$ & 77.5 & $d$ & 2.5 & $d$ & 15.0 & $d$ & 1017 & e & 3.5 & $d$ & 0.45 & b & 3.8 & c & 0.6 & a & 3.5 & $d$ \\
\hline $20 \mathrm{~m}^{3 *} 30 \mathrm{~cm}$ & 92.8 & c & 3.7 & bc & 20.7 & $b$ & 1383 & $d$ & 5.9 & $b$ & 0.56 & $b$ & 4.1 & bc & 0.5 & $b$ & 4.5 & $b$ \\
\hline $25 \mathrm{~m}^{3 *} 30 \mathrm{~cm}$ & 95.0 & $b$ & 4.5 & $\mathrm{a}$ & 22.7 & $b$ & 1833 & b & 6.2 & $a$ & 0.66 & a & 4.4 & $a b$ & 0.4 & c & 4.9 & b \\
\hline Control * $30 \mathrm{~cm}$ & 86.7 & $d$ & 3.9 & $b$ & 19.1 & c & 1533 & $\mathrm{~cd}$ & 5.5 & $\mathrm{~b}$ & 0.48 & b & 3.9 & c & 0.5 & b & 4.0 & c \\
\hline $15 \mathrm{~m}^{3}{ }^{*} 50 \mathrm{~cm}$ & 4.9 & $\mathrm{~cd}$ & 2.9 & $\mathrm{~cd}$ & 19.7 & c & 1400 & $d$ & 4.2 & c & 0.49 & $b$ & 4.2 & $b$ & 0.5 & $a b$ & 3.8 & $d$ \\
\hline $20 \mathrm{~m}^{3 *} 50 \mathrm{~cm}$ & 82.4 & a & 5.1 & $\mathrm{a}$ & 28.0 & a & 2240 & a & 6.8 & a & 0.65 & a & 4.7 & a & 0.4 & c & 5.5 & a \\
\hline $25 \mathrm{~m}^{3 *} 50 \mathrm{~cm}$ & 93.6 & a & 4.9 & a & 26.7 & a & 1900 & b & 6.3 & a & 0.59 & $a b$ & 4.5 & a & 0.4 & c & 5.2 & $a b$ \\
\hline Control * $50 \mathrm{~cm}$ & 8.0 & $\mathrm{~b}$ & 4.2 & $a b$ & 20.4 & $\mathrm{bc}$ & 1610 & $\mathrm{c}$ & 5.9 & $\mathrm{~b}$ & 0.53 & $b$ & 4.1 & $b$ & 0.4 & $\mathrm{bc}$ & 4.1 & c \\
\hline \multicolumn{19}{|c|}{ Second season } \\
\hline \multicolumn{19}{|l|}{$\begin{array}{l}\text { Vermicompost rate } \\
\text { (A) }\end{array}$} \\
\hline $15 \mathrm{~m}^{3} / \mathrm{feddan}$ & 77.5 & C & 2.8 & B & 13.8 & $\mathrm{C}$ & 758 & $\mathrm{D}$ & 2.6 & B & 0.44 & C & 3.6 & B & 0.5 & A & 2.4 & B \\
\hline $20 \mathrm{~m}^{3} /$ feddan & 92.8 & A & 4.4 & A & 23.3 & B & 1183 & $B$ & 5.8 & A & 0.54 & B & 4.1 & $A B$ & 0.4 & $B$ & 2.7 & A \\
\hline $25 \mathrm{~m}^{3} / \mathrm{feddan}$ & 95.0 & A & 5.0 & A & 32.5 & $A$ & 2221 & A & 6.4 & $A$ & 0.60 & A & 4.6 & A & 0.4 & B & 2.8 & A \\
\hline Control & 86.7 & $B$ & 3.2 & $B$ & 20.7 & B & 1008 & C & 3.5 & $B$ & 0.53 & B & 3.7 & B & 0.5 & A & 2.5 & B \\
\hline \multicolumn{19}{|l|}{ Planting Space (B) } \\
\hline $30 \mathrm{~cm}$ & 82.4 & $B$ & 3.6 & $B$ & 20.1 & $\mathrm{~B}$ & 1201 & B & 3.9 & B & 0.50 & B & 3.8 & B & 0.5 & A & 2.5 & B \\
\hline $50 \mathrm{~cm}$ & 93.6 & A & 4.1 & A & 25.1 & A & 1383 & A & 5.2 & $A$ & 0.57 & A & 4.3 & $A$ & 0.4 & $B$ & 2.7 & A \\
\hline Interaction $A^{\star} B$ & & & & & & & & & & & & & & & & & & \\
\hline $15 \mathrm{~m}^{3 *} 30 \mathrm{~cm}$ & 75.0 & c & 2.7 & $b$ & 10.3 & $d$ & 695 & $f$ & 2.1 & $b$ & 0.42 & b & 3.5 & $b$ & 0.6 & a & 2.3 & $b$ \\
\hline $20 \mathrm{~m}^{3 *} 30 \mathrm{~cm}$ & 80.0 & $b$ & 3.9 & $a b$ & 21.8 & bc & 1195 & c & 5.3 & $a$ & 0.48 & b & 3.8 & $a b$ & 0.4 & a & 2.6 & a \\
\hline $25 \mathrm{~m}^{3 \star} 30 \mathrm{~cm}$ & 90.0 & $b$ & 4.6 & a & 30.0 & a & 1170 & c & 5.6 & $a$ & 0.59 & a & 4.2 & $\mathrm{a}$ & 0.4 & $a b$ & 2.6 & a \\
\hline Control * $30 \mathrm{~cm}$ & 84.7 & $b$ & 3.0 & $b$ & 18.3 & C & 945 & e & 2.7 & $\mathrm{~b}$ & 0.49 & b & 3.6 & $b$ & 0.5 & a & 2.4 & $b$ \\
\hline $15 \mathrm{~m}^{3}{ }^{*} 50 \mathrm{~cm}$ & 80.0 & $b$ & 2.8 & $b$ & 17.3 & c & 820 & e & 3.1 & $b$ & 0.46 & b & 3.7 & $b$ & 0.5 & a & 2.6 & $a b$ \\
\hline $20 \mathrm{~m}^{3 *} 50 \mathrm{~cm}$ & 105.7 & $a$ & 4.9 & $a$ & 35.1 & $\mathrm{a}$ & 2471 & a & 6.3 & $a$ & 0.57 & $\mathrm{a}$ & 4.5 & a & 0.4 & b & 2.7 & a \\
\hline $25 \mathrm{~m}^{3 *} 50 \mathrm{~cm}$ & 100.0 & a & 5.3 & $\mathrm{a}$ & 24.9 & $b$ & 1971 & $b$ & 7.2 & a & 0.62 & a & 5.0 & a & 0.4 & $b$ & 2.9 & a \\
\hline Control * $50 \mathrm{~cm}$ & 88.7 & $\mathrm{~b}$ & 3.3 & $\mathrm{~b}$ & 23.0 & $\mathrm{~b}$ & 1070 & d & 4.3 & $a b$ & 0.56 & $\mathrm{a}$ & 3.9 & $\mathrm{a}$ & 0.5 & a & 2.5 & $b$ \\
\hline
\end{tabular}

${ }^{*}$ Similar letters indicate non-significant at 0.05 levels.

** Control $=20 \mathrm{~m}^{3}$ cattle manure $/$ feddan.

coincided with that recommended on vermicompost application for encourging plant growth and quality through increase the available forms of nutrients (nitrates, exchangeable $\mathrm{P}, \mathrm{K}, \mathrm{Ca}$ and $\mathrm{Mg}$ ) for plant uptake of red clover and cucumber (Sainz et al 1998), cowpea Kumari and Ushakumari (2002), straw berry (Arancon et al 2004) and rose (Senthilkumar et al 2004), Vermicomposts are comprised of large amounts of humic substances which release nutrients relatively slowly in the soil that improve its physical and biological properties of soil and in turn rise to much better plant quality (Muscolo et al 1999).

\subsubsection{The effect of vermicompost and plant distances on the properties of yield}

The results of using the vermicompost on the green pods total yield, No. of pods / plant, yield of dry seed, weight of 100 dry seeds, No. of dry seeds/plant and the dry seed content of $\mathrm{N}, \mathrm{P}, \mathrm{K}$, protein and total carbohydrate are presented in Table (5). The results indicated that increasing the 
Table 5. Effect of vermicomposting \%, planting spaces and their interaction on some chemical properties, yield and yield quality of pea green and dry seeds

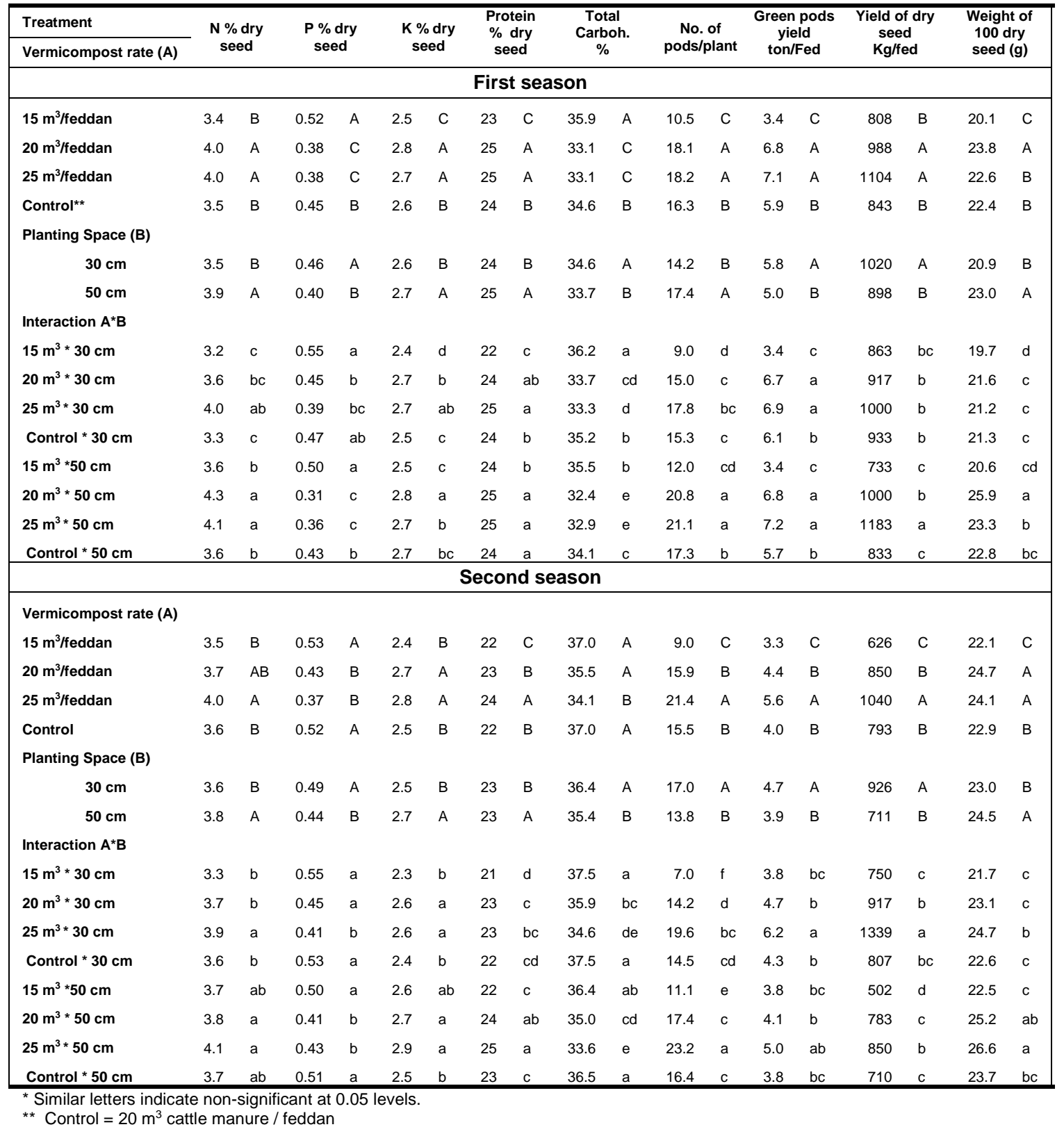

vermicompost rates from 15 to $25 \mathrm{~m}^{3} /$ feddan increased total yield, No. of pods / plant, yield of dry seed, weight of 100 dry seeds, No. of dry seeds/plant, the contents of $\mathrm{N}$ and $\mathrm{K}$ and protein. On the other hand, the increase in vermicompost rate led to decrease $\mathrm{P}$ content in dry seed and total carbohydrates.

The data in Table (5) illustrate that applying inrow plant distance $50 \mathrm{~cm}$ presenteded the higher values of No. of pods / plant, weight of 100 dry seeds, No. of dry seeds/plant, the contents of dry seed $\mathrm{N}$ and $\mathrm{K}$ and protein while the higher values of total green pods yield, dry seed yield, the content of $P$ in dry seed and total carbohydrate were recorded by the application of in-row plant space $30 \mathrm{~cm}$.

The application of vermicompost $25 \mathrm{~m}^{3} / \mathrm{feddan}$ combined with in-row distance $30 \mathrm{~cm}$ gave rise to the highest green pods total yield, No. of pods / plant and dry seed yield. On the other hand, the 
treatment of $25 \mathrm{~m}^{3} /$ feddan combined with in-row distance of $50 \mathrm{~cm}$ gave the highest values of 100 dry seeds weight, the contents of dry seed $\mathrm{N}, \mathrm{K}$ and protein.

Evidances cuaght up from the literature focusing on vermicompost application support our previous results on different crop such as tomato (Patil et al (1998) and Arancon et al (2003), peas (Ramachandra et al (1998) and strawberry (Arancon et al 2004) which showed that the application of vermicompost enhanced soil fertility and improved soil properties beside increased growth and yield of Pisum sativum (Amir and Fouzia, 2011).

\section{CONCLUSION}

Mitigating $\mathrm{CO}_{2}$ emission and sequestrate organic matter into the soil, which increase soil fertility and sustainability, recycling neglectable organic sources led to the increase of pea plants production, utilize of vermicomposting proccess.

Much of the research on vermicompost has focused on studying plant available nutrients and changes in soil structure and fertility. But the most viable indicator should be the organic soil matter content and its monitoring which are absent in most of studies. A high value compost could be obtained through the proper management of organic wastes (vegetables, fruits and newspaper wastes, etc) beside the animal manures via vermicomposting technology. From our results, it can be recommended that the vermicompost rate of 20 $\mathrm{m}^{3} /$ feddan combined with in-row plant distance of $50 \mathrm{~cm}$ is the most obvious in yielding the highest peas production.

\section{ACKNOWLEDGMENT}

This study was promoting by the activities of "Integrated environmental management of urban organic wastes using vermicomposting and green roof (VCGR) project" funded by Science and Technology Development Fund, Egypt by providing the vermicompost.

\section{REFERENCES}

Adisarwanto, T. and Knight, R. (1997). Effect of sowing date and plant density on yield and yield components in the faba bean. Australian Journal of Agricultural Research 48: 11611168.

Allen, S.E. (1974). Chemical Analysis of Ecological Materials. Black-Well, Oxford, p. 565.
Alves, W.L., and Passoni, A.A. (1997). Compost and vermicompost of urban solid waste in $\mathrm{Li}$ cania tomentosa (Benth) seedlings production to arborization. Pesqui. Agropecu. Bras. 32(10): 1053-1058.

Aira, M., Monroy, F., and Dominguez, J. (2007). Microbial biomass governs enzyme activity decay during ageing of worm-worked substrates through vermicomposting. Journal of Environmental Quality, 36: 448-452.

Amir, K. and Fouzia Ishaq (2011). Chemical nutrient analysis of different composts (Vermicompost and Pitcompost) and their effect on the growth of a vegetative crop Pisum sativum. Asian Journal of Plant Science and Research,1(1):116-130.

Arancon, N.Q., Edwards, C.A., Bierman, P., Metzger, J., Lee, S. and Welch, C. (2003). Applications of vermicomposts to tomatoes and peppers grown in the field and strawberries grown unger high plastic tunnels. Proceedings of the International Earthworm Symposium, Cardiff Wales. Pedobiologia 47: 731-735. http://bioorama.gr/pdf/applications_of_vermico mposts_to_tomatoes_and_peppers.pdf

Arancon, N.Q., Edwards C.A., Atiyeh, R.M. and Metzger, J.D. (2004). Effects of vermicomposts produced from food waste on greenhouse peppers. Bioresource Technology, 93: 139-144.

Armstrong, P.W., Matthews, N.A., Fettell, D.J., Holding, L.G., Gaynor1, C.J. and Cullis, L. (2008). Effects of plant density on the yield of field pea and faba bean varieties across southern and central NSW-preliminary findings. Proceedings of $14^{\text {th }}$ Agronomy Conference 2008, 21-25 September 2008, Adelaide, South Australia.

http://www.regional.org.au/au/asa/2008/poster/farmer -focussed-research/5875_armstrongel.htm

Bansal, S. and Kapoor, K.K. (2000). Vermicomposting of crop residues and cattle dung with Eisenia foetida. Biores. Technol., 73: 95-98.

Chapman, H.D. and Pratt, P.F. (1961). Methods of analysis for soil, plant, and water. University of California, Division of Agric Sci.

Dalzell, H.W., Bidlestone, A.G., Gray, K.R. and Thurairajan, K. (1987). Compost production and use in Tropical and Subtropical Environments. FAO, "Soil Management" Bulletin, 49: 18-36.

Domínguez, J., Aira, M. and Gómez Brandón, M. (2010). Vermicomposting: earthworms enhance the work of microbes. In: H. Insam, I. FrankeWhittle and M. Goberna, (Eds.). Microbes at 
Work: From Wastes to Resources. pp. 93114. Springer, Berlin Heidelberg.

Edwards, C.A., Burrows, I., Fletcher, K.E., Jones, B.A., (1985). The use of earthworms for composting farm wastes. In: Gasser, J.K.R. (Ed.), Composting of Agriculture and Other Wastes. Elsevier, Amsterdam, pp. 229-242.

Edwards, C.A., Dominguez, J. and Neuhauser, E.F. (1998). Growth and reproduction of Perionyx excavatus (Perr.) (Megascolecidae) as factors in organic waste management. Biol. Fertil. Soils 27: 155-161.

Food and Agriculture Organization (FAO). (1980). Soil and Plant Analysis. Soils Bulletin, 38: 242-250.

Garg, V.K. and Kaushik, P. (2005). Vermistabilization of textile mill sludge spiked with poultry droppings by an epigeic earthworm Eisenia foetida. Biores. Technol., 96: 1063-1071.

Hand, P., Hayes, W.A., Frankland, J.C. and Satchell, J.E. (1988). The vermicomposting of cow slurry. Pedobiologia 31: 199-209.

Hashemimajd, K., Kalbasi, M., Golchin, A., and Shariatmadari, H. (2004). Comparison of vermicompost and composts as potting media for growth of tomatoes, Journal of Plant Nutrition, 27: 1107-1123.

Inbar, Y., Chen, Y. and Hadar, Y. (1993). Journal of Environmental Quality., 22: 875-863.

Israelsen, O.W. and Hansen V.E. (1962). Irrigation Principles and Practices, $3^{\text {rd }}$ ed John Wiley and Sons, Inc New York, London.

Jettner, R., Loss S.P. and Siddique, K.H.M. and Martin, L.D. (1998a). Responses of faba bean (Vicia faba, L.) to sowing rate in south-western Australia. I. Seed yield and economic optimum plant density. Australian Journal of Agricultural Research, 49: 989-998.

Jettner, R., Loss, S.P., Siddique, K.H.M. and Martin, L.D. (1998b). Responses of faba bean (Vicia faba, L.) to sowing rate in south-western Australia. II. Canopy development, radiation absorption and dry matter partitioning. Australian Journal of Agricultural Research 49: 999-1008.

Kamergam, N., Alagumalai, K. and Daniel, T. (1999). Effect of vermicompost on the growth and yield of green gram (Phaseolus aurus Roxb.). Trop. Agric., 76: 143-146.

Kaushik, P. and Garg, V.K. (2003). Vermicomposting of mixed solid textile mill sludge and cow dung with epigeic earthworm Eisenia foetida. Biores. Technol., 90: 311-316.
Kumari, M.S. and Ushakumari, K. (2002). Effect of vermicompost enriched with rock phosphate on the yield and uptake of nutrients in cowpea (Vigna unguinculata, L. WALP). J. Trop. Agric., 40: 27-30.

Logsdon, G. (1994). World wide progress in vermicomposting. Biocycle, 35: 63-65.

Lunt, H.A. and Jacobson, H.G. (1994). The chemical composition of earthworm casts. Soil Sc., 58: 367-375.

Lemerle, D., Cousens, R.D., Gill G.S., Peltzer S.J., Moerkerk, M., Murphy, C.E., Collins, D. and Cullis, B.R. (2004). Reliability of higher seeding rates of wheat for increased competitiveness with weeds in low rainfall environments. Journal of Agricultural Science, 142: 395-409.

Lemerle, D., Verbeek, B. and Diffey, S. (2006). Influences of field pea (Pisum sativum) density on grain yield and competitiveness with annual ryegrass (Lolium rigidum) in south-eastern Australia. Australian Journal of Experimental Agriculture, 46: 1465-1472.

Marcellos, H. and Constable, G.A. (1986). Effects of plant density and sowing date on grain yield of faba beans (Vicia faba L.) in northern New South Wales. Australian Journal of Experimental Agriculture, 26: 493-496.

Matthews, P.W., Carpenter, D.J., Smith, A. and Fettell, N. (2001). Faba bean seeding rates for central and southern NSW. Proceedings of the 10th Australian Agronomy Conference, Hobart. Australian Society of Agronomy. http://www.regional.org.au/au/asa/2001/6/b/mat thews.htm.

McMurray, L. (2004). Plant density impacts Kaspa field pea's grain yield. Australian Farm Journal Feb 2004. pp 45-46.

McRae, F.J., McCaffery, D.W. and Matthews, P.W. (2008). Winter Crop Variety Sowing Guide. NSW Department of Primary Industries, pp 74-85.

Muscolo, A., Bovalo F., Gionfriddo F. and Nardi F., (1999). Earthworm humic matter produces auxin-like effects on Daucus carota cell growth and nitrate metabolism. Soil Biol. Biochem., 31: 1303-1311.

Patil, M.P., Humani, N.C., Athani, S.I. and Patil, M.G., (1998). Response of new tomato genotype Megha to integrated nutrient management. Advances in Agricultural Research in India, 9: 39-42.

Ramachandra, R., Reddy, M.A.N., Reddy, Y.T.N., Reddy, N.S., Anjanappa, M. and 
Reddy, R. (1998). Effect of organic and inorganic sources of NPK on growth and yield of pea (Pisum sativum). Legume Research 21: 57-60.

Sajid M., Rab, A., Amin, N., Wahid, F., Jan, I., Ahmad, I., Khan, I.A. and Khan, M.A. (2012). Effect of Herbicides and raw spacing on the growth and yield of pea. Pak. J. Weed Sci. Res., 18(1): 1-13.

Sainz, M.J., Taboada-Castro, M.T. and Vilariño, A. (1998). Growth, mineral nutrition and mycorrhizal colonization of red clover and cucumber plants grown in a soil amended with composted urban wastes. Plant and Soil, 205: 85-92.

Senthilkumar, S., Sriramachandrasekharan, M.V. and Haripriya, K. (2004). Effect of vermicompost and fertilizer on the growth and yield of rose. J. Inter academicia, 8: 207-210.

Singh, A. and Sharma, S. (2002). Composting of a crop residue through treatment with microor- ganisms and subsequent vermicomposting. Biores. Technol. 85: 107-111.

Sharma, S.K. (2002). Effect of sowing time and spacing levels on seed production of pea cultivar Arkel. Seed Res., 30: 88-91.

Smith, F.M.A., Hamilton, G.D.K. and Geeds, P.A. (1956). Colorimetric method for determination of sugar and related substances. Anal. Chem., 28: 550-556.

Tejada, M., Gomez, I., Hernandez, T., and Garcia, C. (2010). Utilization of vermicomposts in soil restoration: effects of soil biological properties, Soil Science Society of America Journal, 74: 525-532.

Watanabe, F.S. and Olsen, S.R. (1965). Test of an ascorbic acid method for determining phosphorus in water and $\mathrm{Na} \mathrm{HCO} 3$ extracts from soil. Soil Sci. Soc. Amer. Proc., 29: 677-678.

Waller, R.A. and Duncan, D.B. (1969). Way for the symmetric multiple comparison problem. Amer. Stat. Assoc J., 19: 1485-1503.

Wettstein, D. (1957). Chlorophyll lethal faktoren under submikro skopoch for mvechsel der plastid Exp. cell. Res., 12: 427-433. 